\title{
Filling Position of Governor and Vice Governor of Yogyakarta Special Region in Indonesia
}

\author{
Sugiaryo $^{1, *}$, Pujiyono $^{2}$, Hartiwiningsih $^{2}$ \\ ${ }^{1}$ Students of the Law Doctoral Program of Sebelas Maret University of Surakarta and the State DPK Lecturer of the Faculty of Education \\ and Teacher Training, Indonesia \\ ${ }^{2}$ Faculty of Law, Sebelas Maret University of Surakarta, Indonesia
}

Copyright $(2016$ by authors, all rights reserved. Authors agree that this article remains permanently open access under the terms of the Creative Commons Attribution License 4.0 International License

\begin{abstract}
Act No. 13 Year 2012 on Previleges of Yogyakarta as a Special Region provides a constitutional basis in establishing that the Governor was enthroned as Sultan and to the Vice Governor as Adipati Paku Alam. However, in the case of succession of the Governor of Yogyakarta, there is an exception because it is basically a privileges of DIY that has been existing since Indonesia had not gotten its independent yet and it is also guaranteed by the constitution. The direct appointment of Sultan and Paku Alam is intended to award to the diversity of customs and cultures among the people of different regions. From the results of research and study shows that filling positions of Governor and Vice Governor of Yogyakarta through appointment mechanism is accordance with the principles of a democratic constitutional state.
\end{abstract}

Keywords Position, Governor, State, Democracy

\section{Introduction}

Unitary Republic of Indonesia was founded and built from society with full of diversity ${ }^{[1]}$. The plurality discussed seriously by the founding fathers through the sessions of Agency for Investigating Efforts for the Preparation of Indonesian Independence (BPUPKI) ${ }^{[2]}$, and followed by Preparatory Committee for Indonesian Independence $(\mathrm{PPKI})^{[3]}$. From the results of the sessions, the diversity was accommodated in Article 18 of the Constitution of 1945 which regulates local government, as stipulated by PPKI on August 18, 1945, as follows:

\section{"Regional Distribution of Indonesia in the area} of large and small, with the structure of government is established by law, regarding and remembering consultative basis rather than the system of government, and the rights of the origins of the areas that are special ".
After the Constitution 1945 experienced the amendment, the above provisions have been reaffirmed in Article 18B verse (1) and (2) as follows:

(1). State recognizes and respects the units of local government that is special or distinctive that are regulated by the Act. (2). The State recognizes and respects units of indigenous communities and their traditional rights as long as they live, and in accordance with the development of society and the principles of the Unitary Republic of Indonesia, which is stipulated in the Act. ${ }^{[4]}$

Under the provisions of Article 18B verse (1) has been clear that the position of a privileged area ${ }^{[5]}$ for the province of Yogyakarta Special Region (DIY) has been recognized legally as well as Jakarta

Special Capital Region, as well as Aceh Special Region, although had to wait for the issuance of the Law of Yogyakarta as special region.

Yogyakarta Special Region's privilege is lies in its executive, the head of the region is Sri Sultan Hamengku Buwana and deputy head of the region is Paduka Sri Pakualam, both automatically becomes the Governor and Deputy Governor of Yogyakarta Special Region which is done by appointment.

One of the actualization forms on sovereignty concept is "Regional Chief Election such as Governor and Vice Governor Election" Regional Chief Election Regulation is regulated in Article 18 (4) of the 1945 Constitution. ${ }^{[6]}$

Before the Act of the Republic of Indonesia number 13 year 2012 regarding The Privilege of Yogyakarta, Its privileged, can be traced in the political contract between Yogyakarta Sultanate and the Duchy Pakualaman with the Leader of the Indonesian Revolution, Soekarno (Indonesia First President) as stated in the Speech Coronation HB IX, March 18, 1940; Charter notch lane IX and Sri Paduka Pakualam VIII dated August 19, 1945; Mandate 5 September 1945; Mandate October 30, 1945; The mandate of the Declaration of Independence Homeland.

With the enactment of the Act of the Republic of Indonesia number 13 year 2012 regarding the privilege of 
Yogyakarta, and Regulation of Yogyakarta Special Region (Perdais) No. 1 year 2013 on the authority in matters of the privilege of Yogyakarta Special Region, then the debate on the mechanisms for filling positions of governor and vice governor of Yogyakarta Special Region has ended due to the Act of Privileges of Yogyakarta Special Region (UUK DIY) and Regulation of Yogyakarta Special Region (Perdais DIY) has determined that filling the positions of Governor and Vice Governor of Yogyakarta through the appointment mechanism. ${ }^{[7]}$ The question is whether the mechanisms for filling positions of Governor and Vice Governor as stipulated in the Act of the Republic of Indonesia number 13 year 2012 regarding The Privilege of Yogyakarta, and Regulation of Yogyakarta Special Region (Perdais) No. 1 year 2013 through appointment in accordance with the principles of a democratic constitutional state. It would be interesting to research and study.

\section{Material and Method}

This type of research is the doctrinal ${ }^{[8]}$ research and non doctrinal research. While the approach which is used in this research is the legislation approach, the historical approach, and the based case approach ${ }^{[9]}$. The type of data in this research is secondary data. The data is obtained indirectly by the researcher from the object and subject of research ${ }^{[10]}$. Secondary data in this study include: (1) primary legal materials, consisting of: the Constitution of the Republic of Indonesia Year 1945, Act No. 32 Year 2004 on Regional Government; Act No. 13 Year 2012 on the Privilege of Yogyakarta Special Region; and Regulation of Yogyakarta Special Region (Perdais DIY) No. 1 year 2013 on the Authority in Matters of The Privilege of Yogyakarta Special Region; (2) secondary legal materials, consisting of: books, lecture materials, journals, articles, news sources were associated with this research. Data collection technique in research is literature/study documents. Data analysis technique is deductive logic analysis techniques for solve the problem using the legislation and historical approach. While for the based case approach uses induvtive logic analysis technique. Observations carried out to get an idea about the real condition in Yogyakarta, Indonesia. In addition, researchers also conducted interviews with various groups include; community leaders, religious leaders; courtiers, cemetery and relatives the royal palace, students and professors, members of the legislative (DPRD DIY) and government employees.

\section{Result}

The election law in democratic systems is the real basis of democratic life and the basic principle of building the state institutions ${ }^{[11]}$. In Jordania, the Constitution adopted the principle of separation of three powers. The legislative power is entrusted to the parliament and the King, the executive power to the king and handled by his ministers, and stated that the judiciary is independent power, and it created some sort of cooperation between these authorities ${ }^{[12]}$. Another description of African democracy put forward by African leaders of the post-African independence is based on their argument that traditional African societies rested on a politics of consensus not competition a principle they perceived to be promoted by proponents of multiparty democracy. In the post-colonial era the problem, with this consensus under this so-called African democracy in terms of democratic governance, was that it was to be achieved mainly between the monarch and his/her entourage (mainly relatives from the monarchs' clan, such as uncles and in-laws) and the ruling elites ${ }^{[13]}$. However, it is clear that European elections are in consequence having a considerable and perhaps increasing impact on national politics, beyond what was envisaged in describing them as merely second-order national elections ${ }^{[14]}$. The modest nature of what counts as democratic promise in the Arab world today only underscores how much of a disappointment the Arab Spring has proven to be ${ }^{[15]}$.

In Indonesia, the idea of a constitutional state has been seen from the beginning of the history of the formation of the Republic of Indonesia, specifically the debate between Sukarno and Supomo, Hatta and Yamin on the other. This debate took place when BPUPKI was discussing the material draft of Constitution $1945^{[16]}$. Indonesia Constitutional State is framed in a democratic political system.

H.L Mencken said that democracy is a theory where people know what they need and they deserve ${ }^{[17]}$.

Democracy is government of the people and all for the benefit of the people. Democracy is essentially a constitutional state ${ }^{[18]}$. Democracy is the management of the country through dialogue and voting ${ }^{[19]}$. Democracy is the art of how to use power wisely, so it can be instruments and tools to achieve a society that is just, humane, sharing in plurality and synergy in manifesting all the potential ${ }^{[20]}$. Democracy is a process of dialogue and deliberation. Dealing with the deliberations to reach consensus, Muh. Yamin believed that both of these, is a combination of both, which is deliberation thought is derived from the teachings of Islam, while consensus is sourced from Indonesia original society. Deliberation came from Al Quran surah Ash Shura verse 38 which states that "whose affair is [determined by] consultation among themselves". Regarding the consensus,

Muh Yamin stated that before Islam developed in Indonesia, people in village and other society applied a joint decision $^{[21]}$.

Yogyakarta Province has about 4 million residents, 70\% of them are farmers and laborers, $25 \%$ and $5 \%$ self-employed civil servants, employees of state-owned enterprises and other formal workers. It seems understandable that the farmers and workers tend to support the Sultan. They (still) believe that he a role model, and the slogan "Gesang pejah nderek sultan" (life or dead follow the King/Sultan) still feels quite strong.

According to the tradition that has been prevailing since 
the time Panembahan Senopati ruling until the kingdom of Mataram Yogyakarta Sultanate under the late Sri Sultan Hamengkubuwono $\mathrm{X}$, only the crown prince could be a successor to the throne. There is no direct election by the people to determine who the leader/king them. The king is determined by the previous king through determination/appointment. Adoption of Act No. 13 of 2012 regarding The Previliege of Yogyakarta Special Region, particularly in terms of charging mechanism Position Governor and Vice Governor of DIY indeed have clearly said filling positions by stipulation/determination. However, departing from the current state of the Sultanate as has been described above constituent determination system certainly will not stop until DIY Privileges Act was passed. Because with the Act No. 13 of 2012 regarding The Previliege of Yogyakarta Special Region is like it or not, inevitably will indeed reform Kraton and Pakualaman. So understanding enthroned Sultan and Pakualaman Regional Head DIY automatically become the next must prepare themselves to prepare a successor in accordance with the terms as Governor and Vice Governor.

The results based on interviews are showed that there are differences of opinion on the filling Governor and Vive Governor position in DIY. Society leaders, some religious leaders, students, professors, experts and government officials in general, regardless of whether charging the Governor and Vice Governor Position is done through direct elections or stipulation/determination. Politicians, members of leslative tend to argue follow nature of democracy with an election, but the other groups (academics, courtiers, community leaders) did not make do and tend to agree with the establishment of the King as Governor of Yogyakarta. The group agreed reasoned that, first, this determination has become a tradition passed down since antiquity. So this tradition should be maintained, so that the culture of Yogyakarta Special Region is not be lost. Secondly, during this Yogyakarta Sultanate Palace has facilitated an increase in the welfare of its citizens, the palace has facilitated them, like the land they live on, and so forth. So to say this as a form of reciprocation them to the palace.

And based on the closed interview on 100 respondents mentioned:
a. $96.6 \%$ of the population supports (agree) the DIY privileges.
b. $97.5 \%$ of academics supports (agree) the DIY privileges.
c. $93.2 \%$ of the population support the stipulation/determination sultan as DIY Governor.
d. $94 \%$ of academics support the stipulation/determination sultan as DIY Governor.

While the counter parties by stipulation/determination there are not too many. The main reason disagreement with stipulation/determination process is that the hereditary system of government is not fitting in use in the 20th century. Besides that, there is no structured organizing for this disagreement, so that the opinion of the counter by setting aside is the small amount and also not done openly.

\section{Discussion}

Yogyakarta, become a special region because of three factors: history of its formation which is a combination of the two kingdoms (Sultanate and Pakualaman), Implementation Governed by a democratic system of culture, namely the parliament and traditional institutions and culture (ie Sultanate and Pakualaman), Head Governed by a single dual system, Sultan and Pakualam.

Interpretation 'democratically elected' to 'directly elected', which then lead to problems. The term 'directly elected' is not known in original democratic system in Indonesia. In original democratic system in Indonesia, democratic is implemented by way of deliberation to reach an agreement or consensus, while 'directly elected' is known in Western-style parliamentary democracy.

In addition to differences in interpretation of the term democracy, the emergence of these problems are also due in the Constitution 1945 of the Republic of Indonesia does not regulate election for regional Heads and vice regional head, because the regulation is just for election to elect national parliament members, senators and local parliament members, the President and Vice President. So the regional head election which is done directly, more over put it in the realm of the elections, does not have a constitutional basis.

The absence of a constitutional basis on the election of Regional Head and Vice Regional Head, if it is associated with the theory of the hierarchy of norms (stufenbau theory). Hans Kelsen argues that a norm is made according to the norms of higher and higher norms is created by a higher norm again, and so on until the end on the highest norms, which is stipulated in advance by the public or the people ${ }^{21}$. The highest norm is called Grundnorm or basic norm, which basically does not change. Based on Grundnorm (basic norms), is all laws that are arranged in a unified hierarchical (tiered), starting from the highest positive legal norms to embodiment of the lowest so-called individual norm.

Considering that any legislation must have a legal basis in the higher legislation, then if the lower legislation is in contradiction with higher registration, so the lower legislation should be canceled or null and void.

What distinguishes Yogyakarta with the other autonomous regions is in terms of succession or electing Governor and Vice Governor are not through direct election, but directly determined by the appointment of the Sultan as Governor and Duke Paku Alam as Vice Governor. With the proviso that that could become a Governor and Vice Governor had be Sultan and Paku Alam Duke then there will be no direct election, but the Governor whose term will expire will prepare descendants of the royal family as Crown Prince to replace such customs or traditions of the palace. DIY succession system is different with the other autonomous regions, on the other autonomous regions still refer to Law Number 32 Year 2004 on Local Government 
that states local government has given authority to the regions to elect regional heads directly in accordance with the wishes and aspirations of the people through direct election.

The appointment/stipulation/determination of Sri Sultan Hamengkubuwono and Sri Paduka Paku Alam as Governor and Vice Governor of Yogyakarta Special Region is an example of a special legal exceptions (lex specialis), so that the appointment of the Sultan Hamengkubuwana and Sri Paduka Pakualam as Governor and Vice Governor of Yogyakarta, is positioned as a conditional constitutional rights (fundamental right of Constitutional Condition).

Therefore, the appointment (of Governor and Vice Governor) as a characteristic feature of Yogyakarta Special Region does not violate the constitution, as long as they also gain the support of Yogyakarta community participation. Thus it is clear that the form of the appointment of the Sultan Hamengku Buwana and Sri Paduka Pakualam as Governor and Vice Governor of Yogyakarta Special Region (without direct elections) as provided for in Article 18 and verse (1) of the Constitution 1945 of the Republic of Indonesia is the legal provisions exclusion which is not contrary to the provisions of Article 6 A, Article 18 verse (4) and Article 27 verse (1) of the Constitution 1945 of the Republic of Indonesia.

Based on the judicial aspect, the post of head of the region, the Governor and the Vice Governor as referred to in Article 18 paragraph (4) of the 1945 Constitution which states that governors, regents and mayors are elected democratically. Whereas in Article 18 of Act No. 13 of 2012 states that, Candidates for Governor and Vice Governor candidates are citizens of the Republic of Indonesia must meet the following some requirements, some of them are :

a. Devoted to God Almighty;

b. Loyal to Pancasila as the national principle, The Constitution, Republic of Indonesia and the Government;

c. Enthroned as Sultan Hamengku Buwono for candidates for Governor and enthroned as Duke Paku Alam's candidate for Vice Governor;

d. Educated at least a secondary school or equivalent;

e. To be at least 30 (thirty) years;

f. Not as members of political parties.

In addition to the requirements to become Governor/Vice Governor, Sultan and Paku Alam was not allowed to become members of political parties. Determination Sultan and Paku nature intended as the constitution acknowledged for the diversity of customs and cultures among communities of different regions, especially in maintaining and developing the culture of Yogyakarta, the cultural heritage of the nation.

The mechanism of the charging Position Governor and Vice Governor in Yogyakarta is determinated/stipulated by Parliament and appointed by the President and not elected by the people as well as other provinces. The mechanism for setting the Governor and Vice Governor in brief include:

a. Nomination
Nomination of candidates for Governor from The Sultan and Vice Governor from Paku Alam, who reigns by the Sultanate and the Duchy. When nominating candidates, the Sultanate and the Duchy submit a nomination for a candidate for Governor, signed by Pengageng Kawadenan Hageng Panitrapura Ngayogyakarta Sultanate and Pengageng Kawedanan Hageng Kasentanan Duchy Pakualaman, as well as a statement of willingness of the lane which reigns as a candidate for vice governor, in addition to administrative requirements

\section{b. Files Research}

For verification purposes, the Parliament of DIY formed a Special Committee to Determination Governor and Vice Governor chaired by the Chairman and Vice-Chairman of the Parliament of DIY, as well as members consisting of representatives of the faction.

\section{c. Plenary Determination by Parliament}

Determination Agenda is set at Plenary Session of Parliament. Plenary Session begins with exposure of the vision, mission and programs of candidates for Governor. Minutes stipulation/ determination submitted to the President for approval.

\section{d. Inauguration by the President}

The appointment of Sri Sultan Hamengku Buwana and Sri Paduka Pakualam as Governor and Vice Governor of Yogyakarta Special Region as a form of privilege of Yogyakarta Special Region, has lasted for more than 71 years. Filling the post of Governor and Vice Governor of Yogyakarta through the determination/stipulation is part of its privilege. There are several reasons why this option should continue to be supported. This feature is based on four essential conceptual foundations that can be viewed from philosophical, historical perspective, juridical and socio-cultural, namely :

\section{a. Philosophical Reason}

Conscious choice to become the part of Indonesia is a philosophical reflection of Sultanate, Pakualaman, society of Yogyakarta as a whole that glorifies diversity but singular, that bhineka tunggal ika as set forth in Pancasila and constitution. The Privilege of Yogyakarta could be a solution for that faced of the problem. Therefore, the formulation of the privilege of Yogyakarta Province should be the basis of further strengthening of the multi-cultural society that is able to build harmony and social cohesion.

The term "special" to Yogyakarta is not without purpose. DIY is known as a region rich in cultural potential, both tangible material culture (tangible culture) and intangible value system (intangible culture) . DIY is Known by various predicates such as Struggle City, Student City, City of Culture, Tourism City are adequately describe its merits. In addition, this region also has a long history, even since before the independence of the Republic of Indonesia.

\section{b. Historical-Prespective Reason}


DIY has a distinctive history in itself, which also is part of the history survivalitas of Indonesia as a nation. This distinction is not owned by other regions. Privilege status of Yogyakarta is a conscious political choice taken by the ruler of Yogyakarta, the Lane/Sultan/King IX and Paku Alam VIII, instead of granting of a national political entity. It is important to understand because of the both organization have a complete structure and better prepared to become an independent state before joined to Indonesia.

The appointment Sultan Hamengku Buwono as Governor and Sri Paduka Pakualam as vice Governor does not mean in contradiction with Pancasila democracy but as a form of appreciation and practice of Pancasila democracy, which is based on the spirit of kinship. This was shown when KGPH Herjuno Darpito became KGPH Mangkubumi and later became Sultan Hamengku Buwooa X, was an agreement of the results of the internal deliberations of the Rayi-Rayi dalem, sederek dalem and sentana dalem.

\section{c. Juridical Reason}

The Mandate of Sri Paduka Ingkeng Sinuwun Kanjeng Sultan and Amanat Sri Paduka Kanjeng Gusti Prince Duke Ario Paku Alam can be described as novum which states that the status of Yogyakarta has undergone a change from an area Zelfbesturende landschappen or the Regional Autonomous into an area that is special in the Indonesian territorial. That mandates have been made a normative law, namely Act No. 13 of 2012 on The Previliege of DIY.

\section{d. Socio-Psychological Reasons}

In the last twenty years, Yogyakarta will surely continue to experience social change very dramatically. These developments are not automatically marginalize the centrality of the Sultanate and Pakualaman as an important referral source for the majority of the people of Yogyakarta. Most of the people still perceive and acknowledge the Sultanate and Pakualaman as the center of Javanese culture and a symbol of the protector.

The appointment of Sri Sultan Hamengku Buwono as Governor and Sri Paduka Paku Alam as Vice Governor is the ideals of the people of Yogyakarta for the realization of people's welfare. People of Yogyakarta strongly believe if governor is chaired by Sri Sultan Hamengku Buwono, social welfare will be realized. This is reflected in the title of the King "Sampeyan Dalem ingkang Sinuhun Kanjeng Sultan Hamengku Buwana Senopati Ing Ngalaga Ngabdurrakhman Sayidin Panatagama Khalifatullah ingkang Jumeneng Kaping Sedasa Ing Ngayogyokarta Hadiningrat."

Law enforcement in the filling position of the Governor and Vice Governor of Yogyakarta, must be pursued within the framework of realizing the desire, ability, and messages of the people of Yogyakarta. The appointment of Sri Sultan Hamengku Buwono as Governor and Sri Paduka Pakualam as Vice Governor is the expression of the will of the people of Yogyakarta. Therefore, it cannot be seen as something undemocratic, but provides the rights and freedom of expression to the people of Yogyakarta.

\section{Conclusions}

Based on the research outcome, data analysis and discussion, the conclusions can be stated as follows: Filling position of the Governor and Vice Governor of Yogyakarta Special Region through a mechanism for the determination as set forth in the Act of Privileges of Yogyakarta Special Region (UUK DIY) No. 13 year 2012 and Regulation of Yogyakarta Special Region (Perdais DIY) No. 1 year 2013, in accordance with the principles of a democratic constitutional state, as measured from the six indicators, namely the principle of legality of law, equality law, law enforcement, protection of human rights and the principle of consultation in decision-making.

In order to realize the privilege of Yogyakarta Special Region which is based the principle of recognition of the origin right, citizenship, democracy, unity in diversity (Bhinneka Tunggal Ika), national interests, and the utilization of the interests of local wisdom, it is recommended that filling positions of Governor and Vice Governor of Yogyakarta Special Region is maintained by using the mechanism for appointment.

\section{REFERENCES}

[1] Diversity that is, has the distinction, distinctiveness, and privileges that have existed since the past. Differences in religion and beliefs held, there are Islamic, Hindu, Buddhist, Christian, Catholic and some faiths. Check: Abdurrahman Wahid Pancasila sebagai Ideologi dalam Kehidupan Beragama dan Kepercayaan kepada Tuhan Yang Maha Esa. BP7 Centre, Jakarta, 1991, p. 163-169. Having different customs that are adopted; Acehnese, Batak, Minangkabau, South Sumatra, Indonesia, Bangka Belitung, Kalimantan, Minahasa, Gorontalo, Toraja, South Sulawesi, Ternate, Ambon, New Guinea, Timor, Bali - Lombok, Central and East Java, Surakarta and Yogyakarta and West Java. Check: Slamet Mulyana Kesadaran Nasional dari Kolonialisme sampai Kemerdekaan.. PT. LKIS Rainbow Literacy, Yogyakarta, 2008, p. 315-326. Safroedin Bahar, Nanni Hudawati Sinaga, Ananda B. Kusuma, Risalah Sidang BPUPKI dan PPKI. RI State Secretariat, Jakarta, 1992, p. 26-53.

[2] Saafroedin Bahar, Nanni Hudawati Sinaga, Ananda B. Kusuma, ibid, p. 172 - 324.

[3] ibid.

[4] Act No. 13 Year 2012 on the Privilege of Yogyakarta Special Region; and Regulation of Yogyakarta Special Region (Perdais DIY) No. 1 Year 2013 on the authority in matters of the privilege of Yogyakarta Special Region.

[5] Teguh Prsetyo, Pro Kontra Mekanisme Pemilihan Gubernur Daerah Istimewa Yogyakarta, Papers was presented in the Law Month Agenda, Wednesday, March 6, 2011, in the Faculty of Law UKSW Salatiga.

[6] Marudut Hasugian. The Existence of Democratic Governor Election in Particular Autonomous Framework of Papua 
Province. Journal of Law, Policy and Globalization. Vol.40, 2015. ISSN 2224-3240 (Paper) ISSN 2224-3259 (Online). http://www.iiste.org/. p. 28

[7] Risalah Sidang BPUPKI dan PPKI. Sekretariat Negara RI, Jakarta, 1995, p. 271 - 275

[8] M.Syamsudin, Operasional Penelitian Hukum. Raja Grafindo Persada, Jakarta, 2007, p 25.

[9] Case approach, the approach of this case by performing review of cases relating to the problems encountered. In this research study will be carried out in cases of filling the positions of governor and vice governor Yogyakarta Special Region under the the Act of Privileges of Yogyakarta Special Region (UUK DIY) No. 13 year 2012 and Regulation of Yogyakarta Special Region (Perdais DIY) No. 1 year 2013 from a variety of perspectives of scientific theories.

[10] Syaifuddin Azwar, Metode Penelitian, Pustaka Pelajar, Yogyakarta, 1999, p. 91

[11] Khaled Mohsen. Election under Jordanian Legal Electoral System: a Comparative Study (Jordan, Britain, Germany). International Journal of Humanities and Social Science. Vol. 5, No. 2; February 2015, p.281.

[12] Ibid.p. 283.

[13] Dominique E. Uwizeyimana. Democracy and pretend democracies in Africa: Myths of African democracies. Law
Democracy \& Development Journal. Vol. 16, Year 2012. ISSN: 2077-4907. http://dx.doi.org/10.4314/ldd.v16i1.8. p. 140 .

[14] Michael Marsh. Testing the Second-Order Election Model after Four European Elections. B.J.Pol.S. 28, 591-607. 1998. Cambridge University Press Printed in the United Kingdom. p. 607.

[15] Tareq Masoud. Has The Door Closed on Arab Democrazy? Journal of Democracy, Volume 26, Number 1, January 2015, The John hopkins University Press. http://muse.jhu.edu/article/565640. p. 87.

[16] Risalah Sidang BPUPKI dan PPKI. Op Cit.

[17] Redi Panuju, Oposisi Demokrasi dan Kemakmuran Rakyat. Yogyakarta, Book Publisher, 2009, p. 5.

[18] Muh. Yamin, Naskah Persiapan Undang-Undang Dasar 1945, Yayasan Prapantja, 1959, p. 1-11.

[19] James N. Dan Ziger, Understanding the Political World : A Comparative Introduction to Political Science. Long Man, New York, 1988, p.87.

[20] Frans Magnis Suseno, Etika Politik, PT. Gramedia Pustaka Utama, 1997, p. $26-33$.

[21] Merphin Panjaitan, Logika Demokrasi, Rakyat Mengendalikan Negara, Permata Aksara, Jakarta, 2011,p. 2. 